\title{
Spiritual Counseling for Bereaved Parents
}

\author{
Nur Başer Baykal ${ }^{1}$ (D) \\ Istanbul Zaim University
}

\begin{abstract}
This review aims to understand the psychological conditions of families who have lost one or more of their children, identify topics that can be studied with parents, explain how spirituality can be used while working with bereaved parents, and provide information about how child mourning can be considered within spiritual counseling. This study also presents spiritual resources that can be utilized while working with religious families. The main purpose is to create a framework and to contribute to the counseling process by offering spiritual resources to counselors who will work with religious families that have experienced child loss. The review explains the process of grief and grief theories before discussing topics identified on the basis of the meaning reconstruction model, one of the grief theories, from a spiritual counseling perspective. This will demonstrate that there are spiritually oriented techniques that can be used while working with bereaved families.
\end{abstract}

\section{Keyword}

Spiritual counseling $\bullet$ Grief $\bullet$ Child bereavement $\bullet$ Meaning reconstruction model

\section{Çocuk Kaybı Yaşayan Ailelerle Manevi Danışmanlık}

$\ddot{\mathrm{O} z}$

Bu derlemede, çocuklarını kaybeden ailelerin psikolojik durumlarının anlaşılması, ebeveynlerle birlikte incelenebilen konuların saptanması, yaslı ebeveynlerle çalışırken maneviyatın nasıl kullanılabileceğinin açıklanması ve çocuk yasının nasıl olduğu hakkında bilgi verilmesi amaçlanmıştır. Bu çalışma aynı zamanda dindar ailelerle birlikte çalışılabilecek manevi kaynakları da içermektedir. Ana amaç, bir çerçeve oluşturmak ve çocuk kaybını yaşayan dindar ailelerle birlikte çalışacak danışmanlara manevi kaynaklar sunarak danışmanlık sürecine katkıda bulunmaktır. Derlemede, yas süreci ve yas teorileri açıklanmaktadır. Yas teorilerinden biri olan anlam yapılandırma modeli temel alınarak tanımlanan konular manevi danışmanlık perspektifinden ele alınmaktadır. Aynı zamanda, çocuk kaybı yaşamış ailelerle çalışırken kullanılabilecek manevi tekniklere de yer verilmiştir.

\section{Anahtar Kelimeler}

Manevi danışmanlık • Yas • Çocuk ölümü • Anlam yapılandırma modeli

1 Correspondence to: Nur Başer Baykal, Department of Psychology, Istanbul Zaim University, Halkalı Campus, Kucukcekmece, Istanbul Turkey. Email: nur.baser@izu.edu.tr

Citation: Başer Baykal, N. (2018). Spiritual counseling for bereaved parents. Spiritual Psychology and Counseling, 3, 85-106. http://dx.doi.org/10.12738/spc.2018.1.0039 
In the literature, many studies exist on grief and spirituality in which most authors have focused on the loss of a spouse, parents, a close person, or children. Regarding child loss, the use of religiosity and spirituality has emerged as a major coping factor (Murphy, Johnson, \& Lohan, 2003; Wheleer, 2001) because the grief process is somehow facilitated if the family can find meaning in and explain the loss (Lichtenthal, Currier, Neimeyer, $\&$ Keesee, 2010). Yet, although spirituality and religiosity are very important factors in coping with grief, no specific studies about spiritual counseling in Turkey following the loss of a child are found in the literature. This study therefore makes an important contribution to the literature by combining grief counseling with an Islamic point of view.

\section{Grief Process}

The death of a close relative is a very difficult situation for a person, with the potential to change completely his or her life. A person having lost a loved one can experience very different emotions and exhibit a variety of reactions (Stroebe, Hansson, \& Schut, 2001), whether psychological, physical, behavioral, cognitive, or emotional. While emotional reactions include sadness, fear, anxiety, shame, guilt, anger, loneliness, longing, and helplessness (Worden, 2009), physical and behavioral problems include sleep problems, appetite problems, withdrawal from social settings, crying, feelings of discomfort or uneasiness, and nightmares. Regarding cognitive reactions, people tend to feel low self-esteem, hopelessness, and desperation, and may suffer loss of memory and concentration (Burke \& Neimeyer, 2014; Stroebe et al., 2001). These are all considered normal initial reactions that are expected to decrease with time partly because the person gradually develops the ability to cope with these negative reactions. Opinions about the normal duration of grief reactions vary depending on cultural, contextual, and personal factors (APA, 2013). For this reason, it is vital that a consultant evaluate the person taking these factors into consideration.

\section{Grief Theories}

There are many models and theories explaining grief. These theories can be divided into three basic groups. The first consists of classical theories explaining grief by examining it in the different stages that the person, considered to be passive, must go through. Making up the second group are task models, which, similar to classical theories, consider the person who experiences grief as passive regard him or her as an actor who successfully regains control by undertaking various tasks in the grief process. The third group is relationship maintenance models, which view grieving as an effort to maintain a relationship with the deceased by moving it to a different dimension (Holland, 2001). The latter two models are considered modern models.

Classical theories include Freud's grief theory, Kübler-Koss's five-stage grief model, and Bowlby's grief model (Walter \& McCoyd, 2009). Freud claims that grief 
is a process that enables one to break his or her bond with the deceased. According to this approach, a one must disconnect himself from the deceased in order to regain functionality and to relate to other people (Person, 2009; Smith, 2002). In KüblerRoss's model, the bereaved goes through five stages: (i) rejection, (ii) anger, (iii) bargaining, (iv) depression, and (v) acceptance. Completing these steps enables the person to accept and cope with the death (Holland \& Neimeyer, 2010, Kübler-Ross $\&$ Kessler, 2005). According to Bowlby's theory, the bereaved first enters the shock phase, which is followed by feelings of longing and sadness. After these phases, periods of protest and desperation appear in the third and fourth phases. The final stage is the acceptance phase (Stroebe et al., 2001). Thus, contrary to Freud, Bowlby does not advocate that people break their bonds with the deceased person. Instead, he recommends that since it is more functional for the person to maintain the relationship, they continue to feel intrinsically related to the loved one (Bowlby, 1980).

Classical theories deal solely with the stages of grief without explaining how to deal with it. In addition, they are ineffective in application, lack empirical research support, and standardize the unique experience of each person (Holland \& Neimeyer, 2010). Contemporary theories include a variety of different models, such as the cognitive process model, the meaning reconstruction model, the dual process model, and the task model (Walter \& McCoyd, 2009). Being influenced by social structuralism, these models do not evaluate grief independently from culture, religion, social, and personal factors (Stroebe et al., 2001). Instead, they acknowledge that every loss is unique for each grieving person. Thus, while working with the loss of each client, the counselor needs to adopt different methods and points of view. The following section outlines two modern models considered particularly suitable for a spiritual orientation.

\section{The Task Model}

The Task Model defines four tasks for adapting to life after loss (Worden, 2009):

\section{Accepting the loss,}

2. Working with the loss,

3. Becoming accustomed to the new life in which the lost person does not exist, and

4. Re-arranging the emotional bond with the lost one and continuing with life.

In contrast to classical models, Worden (2009) proposes that the bereaved person actively undertake tasks to deal with grief in order to continue with her or his life. The first task, called external harmony, requires the bereaved person to realize that the loved one has died and is not going to come back. The second task, inner harmony, is to feel and experience the suffering of one's loss, although exactly how this is 
experienced depends on social, cultural, and personal factors. The emotions that usually emerge in people are sadness, anger, and anxiety (Worden, 2009). The third task, spiritual harmony, involves the acceptance of one's beliefs about life and death while also including the first two tasks. The fourth task involves reconnecting and maintaining contact with the deceased person.

Thought to be one of the most effective models used in grief therapy programs, this model does not aim to sever the connection with the deceased but considers that the bereaved person should continue life by maintaining their relationship with the deceased (Stroebe \& Schut, 2010). However, Worden (2009) acknowledges that these four tasks are not sufficient to explain the whole process. He therefore argues that other factors than those in the model may also influence the grief process, such as the bereaved person's level of attachment to the deceased, personality traits, the manner of death, and both social and cultural factors.

\section{Meaning Reconstruction Model}

The meaning reconstruction model is an established model for structuring one's subjective reality in a social context. The model also acknowledges the social context because each person is a part of their environment. Therefore, understanding the culture and the environment in which the person is living is an important factor in understanding and working with the bereaved (Stroebe \& Schut, 2001).

Neimeyer (2011) argues that each person creates his or her own story of life, even if it is based on the social rhetoric of time and space. People turn a micro-narrative of everyday life into a macro-narrative by reinforcing it with their own understandings. This is a form of selfexpression defined as a comprehensive cognitive-emotional-behavioral structure (Neimeyer, 2004). This self-expression affects our feelings, thoughts, goals, and performance on the world stage. Since the loss of a loved one is a shock that fundamentally shakes one's life story, it must be reshaped following this event. People who lose a loved one tend to start seeking meaning, which can be relational (e.g., Am I no longer a mother?), spiritual (e.g., Why did God allow it?), existential (e.g., What is the meaning of life?), or behavioral (e.g., Did I play a part in his death?). People either find the answers to these questions or, if they do not, give up asking and begin to reshape their lives (Neimeyer, 2011).

Neimeyer (2000) creates a new model based primarily on making meaning by including the factors that make up the story. The model includes three main factors to understand and work with grief:

1. Sense making,

2. Benefit finding, and

3. Identity change. 
Sense making is about trying to find a meaningful answer about the loved one's death (Matthews \& Marwit, 2006). This can be achieved by making a statement about the loss based on one's belief and worldview. For example, a bereaved person stating that it was God's will gives meaning to that death. Benefit finding results from positive changes in one's life after the loss, such as beginning to appreciate the meaning of life after the loss or trying to improve other relationships (Davis, NolenHoeksema, \& Larson, 1998). Identity change involves creating a new identity after the loss (Matthews \& Marwit, 2006).

Meaning Reconstruction Theory makes the following five assumptions:

i. Grief should be evaluated as unique for the bereaved person rather than being examined from a universalistic point of view (Neimeyer, 2000).

ii. Classical theories are mistaken in their idea of breaking the bond with the deceased; rather, continuing the inner bond with the deceased is healing (Field, 2006). Neimeyer (2001) suggests that the bond between two people continues after death even though their bond and love changes from a physical to a symbolic connection. A new life story is created through this link with the deceased person.

iii. In addition to emotionally working on grief, cognitive structures are also important. Cognitive interventions can be applied to change the person's viewpoint (Neimeyer, 2000).

iv. The development of the grieving person is directly related to the loss, which includes benefit finding and identity change (Gillies \& Neimeyer, 2006).

v. Since the person's social environment and both family and cultural factors are very influential while dealing with the grief, they cannot be ignored by counselors (Neimeyer, 2000).

Gillies and Neimeyer (2006) proposed the meaningful reconstruction model (Figure 1). This constructivist integration was achieved by including many theories. The model provides a wide perspective to construct meaning and to understand grief. The model includes structures that can be different for each person. In order to understand a person's "assumptions about the world" (Parkes, 1996) and "personal constructs" (Kelly, 1955), it is necessary to have information about six areas related to their lives: (i) their daily activities and priorities (Folkman, 1997; Stroebe \& Schut, 2001), (ii) their self-perceptions and personal identities (Tedeschi \& Calhoun, 1998), (iii) interpersonal relationships (Bowlby, 1980) (iv) views about the future (Thompson, 1985), (v) worldviews in terms of spiritual or philosophical beliefs (McIntosh, Silver, \& Wortman, 1993, Pargament \& Park, 1995), and (vi) significant actions in their social communities (Gillies \& Neimeyer, 2006). 


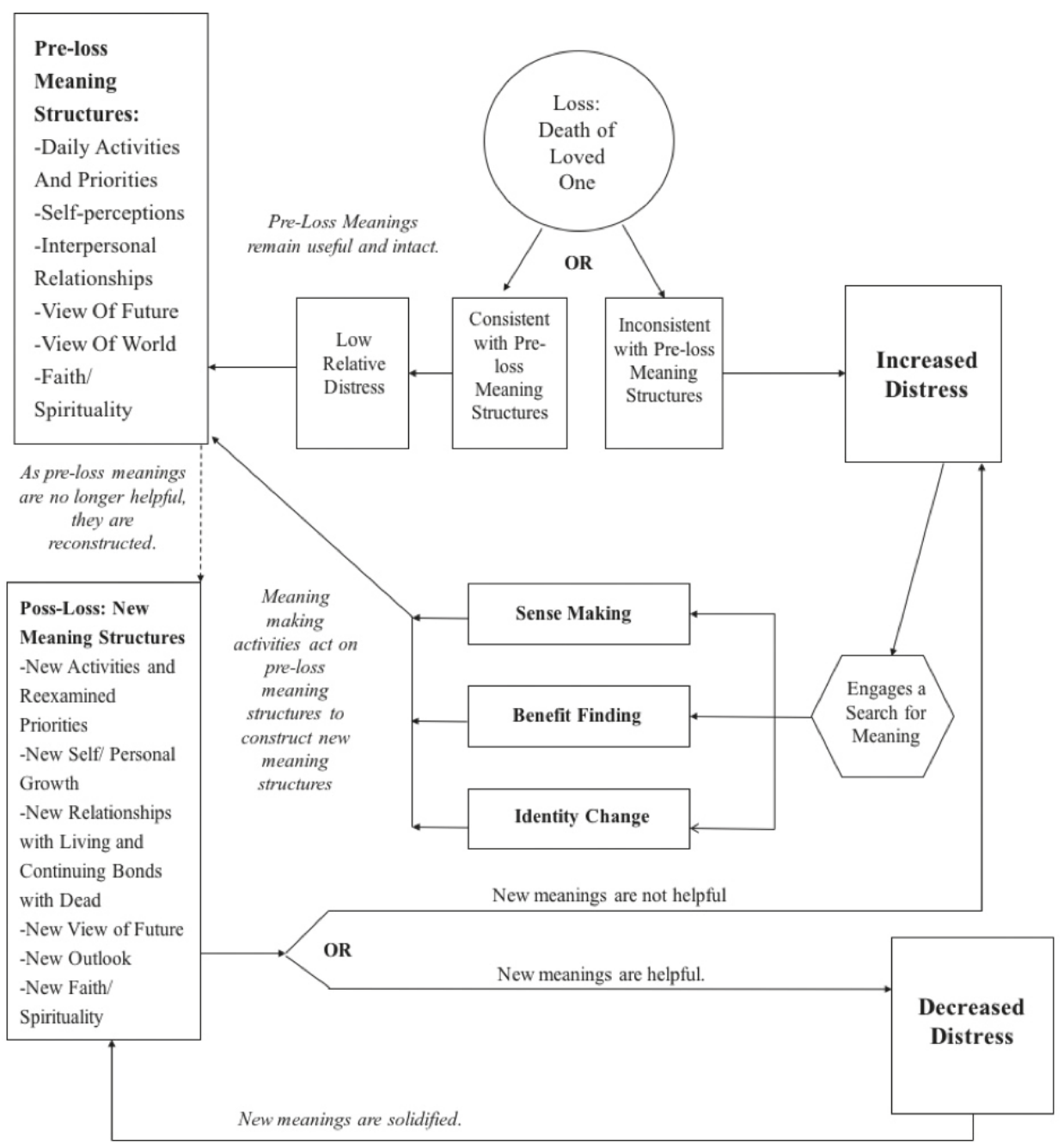

Figure 1. Model of meaning reconstruction pathways in response to the loss of a loved one (Gillies \& Neimeyer, 2006, p. 55).

The model suggests that the death of a loved one may be consistent or inconsistent with the pre-established meaning constructs of the person (Neimeyer, 2005). Losses that conflict with the mental structures of the person are more destructive than nonconflicting. If a person's mind contains a schema about loss that makes sense to the person, s/he will neither have to rethink the process, create new structures, nor struggle with this new event. Even if the event is very stressful, it can be coped with easily if it is consistent with existing mental structures. However, events that are inconsistent with previous meanings are hard to handle and do in fact create stress in the person. In this case, the bereaved person must search for meaning according to the model (Gillies \& Neimeyer, 2006). Neimeyer (2000) includes the following main concepts: 
(i) sense making, (ii) benefit finding, and (iii) identity change. The bereaved person evaluates the old schemes through these concepts and rearranges them, leading them to look at the world from a new point of view. These new constructs help her/him to adapt to a new life.

The distress factor in Figure 1 plays a critical role in the model because distress enables new meaning to be constructed by triggering the search for it. The focus of this constructivist model is on meaning constructs and the processes through which they operate and transform our experience. Thus, distress is not an enemy to avoid or a symptom that should be relieved. Rather, this model provides a mental map of the grief process by using distress in order to help the bereaved person. The pathways for each person and each situation may vary.

This meaning reconstruction model has been used with bereaved parents who have lost a child. Working with such families, Davis et al. (1998) found that $86 \%$ of such families were trying to find meaning. Furthermore, parents who found meaning experienced less physical and psychological distress than those who did not.

Wheeler (2001) used open-ended interviews with 176 bereaved parents to investigate how they found meaning after their loss. The general themes of the questions that parents asked themselves in order to find meaning include understanding why they lost their child, whether they could have done something to prevent the loss, the value of the child's life, and the loss-related benefits. The interviewed parents stated that they had found meaning by communicating with people, through their beliefs and values, by re-establishing connections with their deceased children, and from giving importance to their own personal development. They even reported that they had benefited from this experience and that their identity had changed.

Murphy et al. (2003) conducted a longitudinal study of bereaved family members to determine what meanings parents give to their child's death. They found that although no parent could find meaning within the first four months, over a longer time period of about five years, $60 \%$ of parents said that they had been able to make meaningful sense of their child's death. They reported that those who found meaning were less stressed, more satisfied with their marriage, and had better physical health. More specifically, they found that in the first year after the child's death, the person overcame the idea that this death was unfair. Parents initially sought explanations for or information about the death, made causal inferences according to that information, and questioned their own role in the death. After between one and five years, other issues became more dominant, particularly renewing memories, rituals, revenge or justice seeking, and accepting the lives of the dead children. After five years, themes about benefit finding and identity change came to the fore. These included new perspectives on the meaning of life, re-organization of priorities in life, deepening of 
beliefs, valorization of the deceased child, believing that the suffering of children in the world is ending, becoming more altruistic, struggling with other difficulties more easily, and resilience in the face of difficulties.

Lichtenthal et al. (2010) reported similar results to previous studies (Davis et al., 1998; Murphy et al., 2003), finding that the most common meaning among the 156 parents came from religion and spirituality. Such parents gained meaning from their beliefs that the child's death was the will of God, that the child's life has not ended, and that $\mathrm{s} / \mathrm{he}$ has traveled beyond worldly life. Most parents stated that their spiritual feelings increased following their loss.

\section{Spirituality and Grief}

Religion and spirituality are basic elements holding a crucial place in many people's daily lives. Especially when experiencing loss, people may turn to religion and spirituality because they can make sense of what they are experiencing, gain power to continue their lives, and find explanations about death (Wortmann \& Park, 2008).

The link between religion, spirituality, and death is very obvious. Many religious teachings mention death and life after death with funerals including religious rituals. In addition, religion affords a powerful way of addressing and providing answers to the existential questions that arise in the face of death (Batson \& Stocks, 2004). Religious explanations enable people to make sense of death, cope with loss, and find new meanings (McIntosh et al., 1993; Smith, 2002).

There are many qualitative and quantitative studies about the use of religious resources and spirituality to cope with grief (Wortmann \& Park, 2008) demonstrating that religion is one of the most commonly used and effective means of coping with death. This is because people can only find meaning through religion and spirituality in order to be able to cope with death (Easterling, Gamino, Sewell, \& Stirman, 2000; Pargament, Koenig, \& Perez, 2000).

\section{Studying Bereaved Parents using the Spiritually Orientated Meaning Reconstruction Model}

Child loss is considered one of the most serious, painful, and destructive types of grief. The loss of children affects others for much longer than the loss of other loved ones, and particularly affects parents throughout their remaining life (Malkinson \& Bar-Tur, 2004). Child loss is associated with psychiatric illnesses, existential pain, marital problems, and even increased mortality (Lichtenthal et al., 2010). It is therefore critical to work with those families that ask for support after having lost a child so that they can return to their life. In this section, the topics on which counselors can focus are first determined on the basis of the meaning reconstruction 
model before considering how these topics can be studied using spiritual resources. According to the meaning reconstruction model, the themes to be assessed are (i) acceptance of death, (ii) finding meaning, (iii) continuing ties with dead children, (iv) benefit finding, (v) working with cognitive distortions, and (vi) using social support. These are explained below, both in general terms and specifically in relation to Islam and Turkey specifically.

Acceptance of death. Since bereaved family members often experience the death of a child unexpectedly and have a hard time making sense of it, it can take years to accept, let alone make sense of this death. Those who seek meaning but who cannot find it face the risk of losing harmony and functionality in their lives (Murphy et al., 2003). After the death of a child, the parents may start perceive everything as meaningless, even going so far as to lose all sense of meaning and existence in life and the world (Neimeyer, 2000). For most parents, this event throws into question their own life goals, and even the purpose of their child's life, shaking their sense of self. Thus, while working through the grief of the loss of a child, accepting the child's death is the first step toward readapting to life and finding meaning in it (McIntosh et al., 1993).

Studies show that religion and spirituality are positively related to acceptance of death and adaptation to life (Becker et al., 2007; Park \& Halifaxs, 2011; Wortmann \& Park, 2008). It is therefore important to understand the spiritual and religious perspective of the person in counseling. In order to study parental acceptance of death, it is necessary to understand and work on their religious and spiritual orientation as well as their beliefs about death. If the person is a believer who defines him or herself as a devout person and is willing to work on his or her grief in a spiritually oriented manner, the many explanations and examples about death in Islamic sources (e.g., Qur'an, hadith literature, and prophetic biography) can be used in counseling to help understand and accept death and life after death.

According to Islam, death is not synonymous to the end of life and the complete disappearance of a person. On the contrary, it is the time of transition from worldly life, which is itself a test, to the afterlife and the end of experience in the world. Furthermore, death is an event determined by God occurring at His discretion. Various verses of the Qur'an relating to death can be used for studying death and grief in counseling (see Zumar: 30, Najm: 44, Tawbah: 116, Dukhan: 8, Waqi'ah: 60, Luqman: 34, Jumu'ah: 8, Ahzab: 16).

According to Islamic belief, death is the true returning of the soul. According to Sufi faith, death is not a separation, but a union with God, as indicated, for example, by Jalâl ad-Dîn Rûmî's description of death as "Sheb-i Arus" (wedding day) (Çelik, 2009). Similarly, Quranic proverbs of "returning" or "meeting" are used to refer to death (see An'am: 31, 36, 154, Yûnus: 45, Kahf: 110, Maryam: 40, Yaseen: 22, 43, 
Fajr: 28). In Turkish culture, instead of saying that someone has died, people tend to use verbs like migrate, move, or shift to the other life (Kara, 2017), which prevent one from seeing death as extinction and which thereby encourages the adoption of a different perspective.

Apart from such verses, the counselor can talk with a devout client about stories from the life of the Prophet (saws) and his companions, discussing what $\mathrm{s} / \mathrm{he}$ thinks and feels about the anecdotes. This can then work on the client's feelings and thoughts about accepting death.

Sense making. Professionals working with grief argue that finding meaning in the experience of loss and continuing life without the lost person in question reduces the suffering of the bereaved person and helps them heal (Neimeyer, 2000). Meaningbased interventions are influential in finding meaning, adapting, and healing (Lichtenthal et al., 2010; Michael, Crowther, Schmid, \& Allen, 2003).

Lichtenthal et al. (2010), Davis et al. (1998), and Murphy et al. (2003) have shown that religion and spirituality are the most common source for finding meaning. From working with a bereaved family, McIntosh et al. (1993) noted that religion has a positive and significant relationship with meaningfulness. Similarly, Uren and Wastell (2002) found that $80 \%$ of mothers whose child had died were trying to find a religious meaning in the death. For this reason, religious factors can be used in grief therapy to find meaning. Various Qur'anic verses from Islam can be used to find meaning in a child's death: "No soul can die except by God's leave, at a predetermined time" (Imran: 145); "No disaster occurs except by God's leave. Whoever believes in God, He guides his heart. God is Aware of everything" (Teghabun: 11); "Your possessions and your children are a test, but with God is a splendid reward" (Teghabun: 15); "And know that your possessions and your children are a test, and that God possesses an immense reward" (Anfal: 28). These verses can help one define death as reflecting fate and the will of God in order to eliminate feelings of guilt. It also gives parents a sense of meaning and endurance to think that this worldly life is merely transient whereas death is an eternal reunion with God (Rubin \& Yasien-Esmael, 2004).

The counselor must be extremely careful while trying to find a parent's religious meaning, since while the meaning of these verses is that worldly life is both temporary and a test, it does not entail that a person will not endure hardships. Indeed, to be an example to other people, the Prophet Muhammad (saws) also lost his son:

After his two sons (Qasim and Abdullah) passed away, he had another son, Ibraham. who became sick when he was 18 months and his disease continued to progress. The Prophet, seeing his son was sick, began to cry. The companions around him said: 'You are crying too, Messenger of Allah, and the Ummah who is in your position will cry.' Prophet Muhammad replied: 'We shed tears, the heart is sad, but we will only say what with which our Lord will be pleased.' When his 
son died, he said: 'If there was not a word and a way to go, and if people had not come together in the afterlife, then we would have thought of different things. O Ibraham! We are really sad because of you. (Muslim, 67; Ibn-i Sa'd, 137; Bukhari, 43; cited in Hadislerle İslam, 2003).

As can be understood from this example, losing a child is extremely difficult for all people, and religious resources support it. To find meaning is not to view suffering as unimportant; on the contrary, the aim is to help one gain a new point of view in order to find consolation from this sadness.

Bonding with the child. Freud argued that in order to cope with death, one must break his or her relationship with the deceased and strengthen relationships with new people (Person, 2009). However, modern grief research shows that people feel better if they continue to connect with the deceased person and feel that they are in contact with them (Field, 2006; Lichtenthal et al., 2010).

Gerrish, Neimeyer, and Bailey (2014) interviewed 13 mothers who had lost their children. Although their grief processes were very different, they all cited their belief that they had a continuing (symbolic or internalized) connection with their deceased children and that this would continue throughout their remaining life. All continued their relationship with different methods, including remembering their children through rituals (e.g., visiting the cemetery, remembering the anniversaries of their deaths), talking with their children (e.g., speaking out loud to tell them they still love them), holding spiritual meetings with the child (e.g., to feel their presence), maintaining close relationships with their grandchildren, and engaging in community activities. One mother described how she learned to live with the name of an invisible child and said that her bond with her child would never end.

It is important for parents to believe in life after death in order to continue their relationship with the child, and such parents are more easily able to cope with the death of their children (Park \& Halifaxs, 2011; Wortmann \& Park, 2008). Those people who believe that the body merely died for a temporary period of time whereas the soul does not die are more likely to continue communicating with their children (Park \& Halifaxs, 2011). Islam discusses this issue in terms of resurrection and waiting for the family in the afterlife. There are many verses that can be referenced in this regard (see A'raf: 57, Rum: 19, Fatir: 9, Jathiyah: 5, An'am: 95, Yaseen: 33, Hadid: 17, Hajj: 5, Nahl: 5, Baqarah: 164).

Sometimes, even parents who do not believe in life after death say they have a spiritual connection and communicate with their dead child. Some clients believe that their child is watching over them and has inspired important decisions. Understanding and listening to these experiences non-judgmentally is crucial for a counselor (Tedeschi \& Calhoun, 2004). These spiritual connections and contacts can take various forms, such as daydreams, dreams, and/or unexplained situations. The 
counselor should not question the accuracy of these statements but should instead allow the client to describe the situation and try to understand it in a way that supports the client effectively. For example, as one parent who lost his religious belief after the death of his son described it (Tedeschi et al., 2004, p.119):

I wanted to look at my son's annuals. I looked through everywhere, but I could not find them. I moved to another room; when I got back, there was a box in front of the washing machine and there were annuals in it. I have no idea where they came from; nobody was at home. I thought it was definitely my son that brought them.

Another way of maintaining the bond with one's child is to remember him or her. Thus, it is both essential and valuable that parents ensure that their dead child is not forgotten by other people. They can organize activities such as charity activities, talks, memorial ceremonies, or prayers on the child's behalf. These activities are good for the family and should be supported (Tedeschi \& Calhoun, 2004). Most religious traditions include funerals and special prayers and other activities that help bereaved people complete the grief process and return to their normal lives (Park \& Halifaxs, 2011). Such religious and cultural activities are widely conducted after loss in Turkey. For example, the Qur'an is read on the seventh and fortieth days following a death, which provides both a connection with the deceased person and allows the grieving family to complete their religious duties for their dead child (Kara, 2016).

There are many Islamically-influenced practices in Turkish culture to ensure that the child is remembered. For example, on religious holidays, the tomb of the child is visited so that family members may place flowers on the grave and decorate it, to read the Qur'an over the grave so as to send it to the soul of the child (Rubin \& Yasien-Esmael, 2004). These practices are not limited to the grave itself as other rituals are frequently followed in Turkey, such as hanging photographs in the house, funding a mosque or educational institution in memory of the dead child, planting trees on the child's behalf, and giving the same name to the next child. These practices all share the purpose of connecting with the deceased child and keeping his or her memory alive.

Benefit finding. Benefit finding refers to parents accepting their loss and recognizing the positive changes in their life from finding meaning in the loss (Davis et al., 1998). Some of these changes are appreciating the meaning of life and improving relationships with other people. Some people experience a religious awakening after their child's death causing them to become more religious (Burke \& Neimeyer, 2014).

Various studies report that parents whose child has died mention various benefits: (i) gaining a new perspective and appreciation of life, (ii) understanding what is really important in life, (iii) living life more meaningfully, (iv) having positive effects on others (e.g., adopting or helping children), (v) dealing more closely with other people, 
(vi) deeper spiritual and religious understanding, (vii) becoming a better person, and (viii) realizing what they can tolerate. As one parent explained (Wheeler, 2001, p. 59):

Now I understand better that there is a gift in this tragedy and [that] it is up to us to find it, He taught us life and death, my child was the window of my life. I realized that what is important is not the life time in life, but the quality of life. I learned that I am stronger and able to withstand everything.

Davis and Nolen-Hoeksema (2001) found that the ability of a family to benefit from the death of their child also depends on personality factors in that more positive individuals tended to benefit more easily whereas not much changed in the lives of pessimists. They also found that even if parents can find meaning within the first six months, they still need more time for benefit finding as a higher-level coping mechanism that emerges over time. Thus, while finding meaning is an effective tool that emerges in the first few months after the child's death, benefit finding is a higherlevel coping mechanism that emerges in families that is strengthened over time.

Another positive change that occurs in parents who believe in the afterlife is reduced anxiety toward the death. Parents who think their child is waiting for them in heaven and that they will see him or her look forward to this encounter (Tedeschi \& Calhoun, 2004). Religious schemes regulate beliefs about death while religious perspectives reduce fear and anxiety about death. This strengthens the person (McIntosh et al., 1993). People with beliefs also tend to have higher empathy and emotional affinity for others (Tameschi, Park, \& Calhoun, 1998). Thus, while those who have lost a child increase in both sadness and wisdom as a result of this difficult process, they change positively in spiritual and existential terms.

One of the thoughts that encourages positive thinking from a spiritual point of view in both Christianity and Islam is that the deceased child will protect the person from hell (Vasegh, 2009). One of the sources that can be used regarding this subject in Islam is hadith literature. Several hadiths say that although the parents of a child who has died suffer a great pain, they will, in return, gain the reward of eternal happiness and reconnection with their child. For example, "There is no Muslim who loses three of his children before they reach the age of puberty, but Allah will admit him to Paradise by virtue of His Mercy towards them" (Hadith al-Bukhari, 1299) and also, Allah's Messenger said, 'If any member of my people has two children who die before him, Allah will cause him to enter Paradise on their account. Aisha asked, "Does it apply to a member of your people who has one child who dies before him?" He replied, it does, you who have been helped by Allah to ask this. She then asked, what about a member of your people who has no children who die before him? He replied, I am the one who dies before my people, and they will never suffer any loss to compare with the loss of me." (Hadith Al-Tirmidhi, 1735). Another example is that the daughter of the Prophet (peace be upon him) sent for the Prophet requesting 
him to come as her child was dying [or was gasping], but the Prophet returned the messenger and told him to convey his greeting to her and say: "Whatever Allah takes is for Him and whatever He gives, is for Him, and everything with Him has a limited fixed term [in this world] and so she should be patient and hope for Allah's reward (Hadith al-Bukhari, 2373).

Working with cognitive distortions. According to the meaning reconstruction model, it is very important in dealing with grief to work with cognitive structures in addition to emotional ones. Cognitive interventions, which can be implemented using a spiritual counseling perspective, can change the person's point of view (Neimeyer, 2000). The main cognitive themes able to be considered regarding child loss are as follows:

Seeing death as punishment. Some parents may view their child's death as a punishment and think they deserve it because of some sin that they had committed. When parents interpret their child's death in this way, psychological recovery and adaptation to this situation are severely hindered (Pargament, 1997). However, such people can be counselled using religious resources (Vagesh, 2009). In working with such cognitive distortions, Qur'anic verses and other religious writings that show how compassionate and forgiving God is can be used (see Nisa:110, A'raf: 151, Yusuf: 92, Isra: 66, Anbiya: 83, Hajj: 65, Mu'minun: 118, Shu'ara: 9). The basic belief derived from these verses and hadiths is that God is merciful enough not to torment His creation. The counselor can therefore ask, "Could you have given such a punishment to your child?" A systematic skeptical questioning technique can be used to show that there is no relationship between death and punishment (Leahy, 2004), which can help change the client's distorted cognitive system by referencing others and using double standard techniques (for these techniques, see Savaşır, Boyacıoğlu, $\&$ Kabakç1, 1996). Clients can be asked whether they believe that people who are sinners necessarily lose their children. Such questioning aims to show that it is unreasonable to regard the child's death as a punishment and instead aim to substitute an alternative explanation or meaning.

Feeling guilty. Some parents blame themselves for the death of their children, making similar statements as the following: "I could have prevented this from happening," "I played a role in this event," or "I think that my child would not have died if I had behaved differently." Such cognitive distortions, which harm the health of the parents, can be treated using various Qur'anic verses and other religious works (see Waqi'ah: 60, Qamar: 49, Furqan: 2, Hadid: 22, Najm: 44). The common theme in these verses is that death is at God's discretion meaning that no one else can control it, a belief that can help relieve the parent from guilt. The client can be told directly that a person can neither prevent nor cause death. 
Tedeschi and Calhoun (2004, p.131) offer the following example of a discussion between a counselor and client. In this case, Brian, aged 17, took his mother's car out at night and died in a traffic accident.

Client: I did everything wrong, I got pregnant at 16; I used alcohol; I left my husband. God knew all of these things and eventually said: "Enough is enough, you have used all your luck, and you still have not learned anything; now you see" and he took Brian from me.

Counselor: Do you see Brian's death as a punishment from God?

Client: God knew I was not a good mother, and He could not stand to see me as his (Brian's) mother anymore.

Counselor: So God treated you like social services?

Client: Yes, but even worse; Brian will never come back

In the following section, the counselor and client refer to the belief in Christianity that Jesus (as) paid for the believers' sins and that God sent good people to the client to help.

Counselor: Brian did something he should not have done and went out late at night taking the car; he made the wrong choice so he is responsible for this decision.

Client: Yes I know, but I should have taught him that he should not do it; it is my fault.

Counselor: Yes, but I think Brian already knew it was wrong.

Client: Yes, he knew he should not.

Counselor: Well, now that we have already talked about you and Brian's role, what do you think about God's role here?

Client: His heart was broken and he followed me and Brian's mistakes and sent these good people to help me. He's actually very merciful.

The counselor here tried to expand the client's thought structure by questioning the client's thought that God was punitive and accusing himself, and by considering his client's religious beliefs (such as in Jesus (as), God and God's will). Thus, counselors may be able to change the client's thoughts by helping them with their religious beliefs without trying to convince them or avoiding arguing them.

\section{Religion and Spirituality as Social Support}

Social support is a vital means to help one cope with negative events (McIntosh et al., 1993; Wortmann \& Park, 2008). People are able to cope more easily with sadness if they have religious connections and social environments (McIntosh et al., 1993). 
Grief is as much a social as it is an individual event. It is therefore very important how family and other social groups support the person; social groups can help the bereaved to reengage with life more quickly (Neimeyer, 2006). Those with spiritual experiences and who participate in a supportive group, such as a church group, are better able to cope with grief and experience fewer negative effects of loss (Easterling et al., 2000).

Other studies show that participating in religious social groups has a positive psychological effect on parents who lose their child as such participants report fewer depressive symptoms and less distress (Bohannon, 1991; Higgins, 2002). In addition, members of religious social groups report receiving a lot of social support and say that they felt better when they were checked on after a certain period of time (McIntosh et al., 1993). Murphy et al. (2003) found that parents who participated in a support group after losing their child expressed four times more meaning in life than those who did not. Parents also state that they learn to deal with their grief and sorrow after participating in a support group (Reilly-Smorawski, Armstrong, \& Catlin, 2002).

In the light of these studies, it can be said that bereaved parents should be included in a social group and also be supported by both their families and a religious social group as this will help them to readapt more quickly to community life. Counselors can plan for support groups and group work by considering this when working with bereaved families, or they may advise such families to participate in social or religious group activities.

\section{Spiritually Orientated Techniques for Bereaved Parents}

While working with child loss, a safe and supportive relationship with deep and empathetic listening is crucial. After establishing a safe and profound relationship, various therapeutic strategies can be adopted: psycho-education related to the loss, narration of the client's story, investigation of spiritual and existential concerns, regulation of emotional and cognitive functions, and the use of available power resources. The ultimate goal is to adapt to the loss and to one's new life. Concrete spiritual therapeutic techniques can be used to achieve these goals (Lichtenthal et al., 2010).

Involving spirituality in the sessions. Various strategies can be used to introduce spirituality into the session (Hays \& Hendrix, 2008):

i. Asking whether the client's religious beliefs help him or her to understand the loss and, if so, how they help.

ii. Including a religious chaplain who can provide accurate information on religious matters during consultation. 
iii. Ensuring that the counselor fully understands the spiritual point of view and beliefs of the client in order to avoid prejudice and insensitivity.

iv. For the counselor to avoid presenting his or her own religious ideas or worship style as this is often not beneficial whereas arrangements and interventions made in the direction of client's own beliefs will work.

v. Investigating what family members believe regarding the nature of the death in question and learning what rituals they need to perform, as failure to conduct rituals believed to be necessary in the client's belief system may cause unresolved and prolonged grief.

Writing letters. If the counselor sees that the client has a special connection with the deceased child, s/he must support this bond and help maintain the relationship, for example through prayer, internal speech, meditation, or letters (Neimeyer, 1999).

The letter is both a way of relaxing by typing and a means of both maintaining connection with and talking to the child. Such letters can be written both to the child and to God in order to express clients' feelings about the death of the child and what they want to say to God. Writing can provide comfort, improve physical and psychological well-being, and facilitate coping (Smyth, True, \& Souto, 2001).

Spiritual journaling. Spiritual journaling (i.e., recording one's meaning about the loss or writing about the search for it) is one of the ways to find meaning in the loss, to calm oneself and to make the loss more bearable (Lichtenthal \& Cruess, 2010). A spiritual diary allows bereaved people to use meaning as a tool within their own religious framework and harmonize the cognitive functioning with the mental experience. Parents who mourn according to the meaningful construct model can compare their religious or spiritual perceptions before and after the loss through such a diary technique. This enables them to make their religious perceptions more useful to themselves (such as resolving inconsistencies between what they believe and what they experience). The purpose of keeping a spiritual diary is to facilitate the grief process, to increase resilience, to comfort the person, and to provide spiritual care (Pearce \& Smigelsky, 2015).

The client is asked to write about the relationship between their religious and spiritual beliefs and their loss three times a week for 20 minutes. The article includes the following general themes: (i) the kinds of meaning given to the death, (ii) all kinds of change in life as a result of the loss, (iii) the place of the loss in the client's spiritual and religious system, (iv) the loss's effects on the client's goals in life, (v) relationships and religious or spiritual belief system, and (vi) the loss's potential value and importance for the client's future life. The only rule is that the client writes for the full time period, including everything that comes to mind without revising 
anything. Clients should be warned that they may experience some difficulties at first but that this is temporary and that they will benefit in the long term. Counselors should follow up on these written experiences, spiritual crises, or emerging spiritual themes in further sessions.

This technique can be used to find meaning in the grief process for adults who have differentiated their spiritual beliefs and identities after their loss, or who consider religion and spirituality important. The client decides whether to share this journey with the counsellor. However, such a technique is not suitable for individuals who have recently experienced loss and need supportive interventions.

Research into spiritual journaling has already shown that the technique reduces symptoms of depression and stress, increases understanding, and improves physical health (Pearce \& Smigelsky, 2015).

Spiritually based rituals. The loss of a child deeply affects the identity of the parent. Spiritual rituals therefore aim to transform the old painful self, which is directly related to the child's death, in order to find meaning. This can help by creating intensive, experiential, and symbolic structures for the formation of a new self (Chew, 2015; Gilligan, 1993). Such rituals help parents create a new self by externalizing the feelings of guilt and isolation experienced by the old self.

The ritual is developed and conducted in four stages. First, the symptom to be changed is identified and defined, which requires the client to be fully cooperating and motivated. After this, a ritual can be planned. The client is asked to choose both a physical symbol that symbolizes his or her old self (e.g., clothes, books, photographs, etc.) and one to symbolize the new self, along with a relevant ritual (e.g., burial, burning, or sealing) and a suitable time, place, and number of attendees. To prepare for this ritual, it is desirable to widen the client's experiential and symbolic focus (e.g. by reading religious texts, meditation, prayer, or spiritual journal writing). In the third step, the ritual is performed, and in the final stage, the client talks about the remains of their old self and decides on structures (e.g. a new outfit, activity, or symbol) to express his or her new self (Chew, 2015).

Spiritually based rituals can be used for parents who embrace spiritual values and who attach importance to symbolic values. However, it may not be suitable for those who cannot deal with emotional intensity. It is also critical that the client be willing as the technique requires their cooperation. Such rituals connect past, present, and future, thereby helping the client to gain meaning from their loss. It is important to understand how the client uses religion and spirituality in the context of the loss. Since the emotional ritual experience of each client differs, the location and timing of an appropriate activity for the client should be well planned and the client should not be 
left alone. The cultural structure of the client should also be considered. For example, it may be better for some clients to pray, instead of burning or writing (Chew, 2015).

Working with guilt. As already noted, parents often feel guilty when their child dies. Conversely, if this sense of guilt is not operating, it can also block positive memories and delay healing. Therefore, once a safe counselor-client relationship has been established, this feeling of guilt should be normalized. That is, it should be emphasized that it is normal after a child's death to feel guilty as a sign that the relationship with the child was meaningful and loving. Following this, the sense of guilt should be investigated a little more: "Is this real guilt or does the parent feel guilty for surviving," or "Did the parent do something that caused their child's death?" The client's feelings of guilt should be accepted and allowed (Miller \& Loring, 2015) while various religious or spiritual resources can be used to alleviate them.

If the parents believe that they really did play a role in the death, they should be asked whether they would like to ask to repent or for forgiveness. If they want to use this spiritually orientated technique, they are asked to list the following: "What else could they have done?" "What could they have done better?" "What did they do at that moment?" and "What do they know now but did not know then?" After writing their answers, a deep breath and a simple sentence is required to request God's forgiveness. The process ends by praying for remorse and healing for their regrets (Miller \& Loring, 2015).

\section{Conclusion}

This article addressed counselors who work with clients who have experienced the death of one of their children. First, the grief process was outlined and various theories of grief were explained. Following this, theories and practices based on the meaning reconstruction model that can help counselors support such clients were discussed. Six topics that the spiritually oriented meaning reconstruction model considers important in therapy for child loss were examined: (i) acceptance of death, (ii) sense making, (iii) continuing to bond with the dead child, (iv) benefit finding, (v) working on cognitive distortions, and (vi) social support. The article ended by suggesting various spiritually oriented counseling techniques.

Although parental recovery from child loss is closely related to spirituality and religion, no previous studies in Turkey have compiled practical information that can be used in counseling, nor have they implemented spiritual counseling practices or tested their effectiveness. Although applications have been developed from studies conducted in other counties, these practices may well be unsuitable for clients in Turkey because they reflect the influence of different cultures and religions. There is therefore a great need for applications developed to work with grief that consider Turkish culture and religion specifically. 


\section{References}

Amerikan Psikiyatri Birliği. (2013). Ruhsal bozukluklarin tanısal ve sayımsal el kitabı (DSM-5) tanı ölçütleri başvuru el kitabı (E. Köroğlu, Çev.). Ankara: Hekimler Yayın Birliği.

Batson, C. D., \& Stocks, E. L. (2004). Religion: Its core psychological functions. In J. Greenberg, S. L. Koole, \& T. Pyszczynski (Eds.), Handbook of experimental existential psychology (pp. 141-155). New York, NY: Guilford Press.

Becker, G., Xander, C. J., Blum, H. E., Lutterbach, J., Momm, F., Gysels, M., \& Higginson, I. J. (2007). Do religious or spiritual beliefs influence bereavement? A systematic review. Palliative Medicine, 21(3), 207-217.

Bohannon, J. R. (1991). Grief responses of spouses following the death of a child: A longitudinal study. Omega-Journal of Death and Dying, 22(2), 109-121.

Bowlby, J. (1980). Attachment and loss: Vol. 3. Loss: Sadness and depression. London, UK: Hogarth.

Burke, L. A., \& Neimeyer R. A. (2014). Spiritual distress in bereavement: Evolution of a research program. Religions, 5(4), 1087-1115.

Chew, J. H. F. (2015). Spiritually based healing rituals. In R. A. Neimeyer (Eds.), Techniques of grief therapy: Assessment and intervention, (pp. 329-331). New York, NY: Routledge.

Çelik, İ. (2009). Türk tasavvuf düşüncesinde ölüm. Atatürk Üniversitesi Türkiyat Araştırmaları Enstitüsü Dergisi, 16(40), 119-146.

Davis, C. G., Nolen-Hoeksema, S., \& Larson, J. (1998). Making sense of loss and benefiting from the experience: Two construals of meaning. Journal of Personality and Social Psychology, 75(2), 561-574.

Easterling, L. W., Gamino, L. A., Sewell, K. W., \& Stirman, L. S. (2000). Spiritual experience, church attendance, and bereavement. Journal of Pastoral Care, 54, 263-275.

Field, N. P. (2006). Continuing bonds in adaptation to bereavement: Introduction. Death Studies, 30(8), 709-714.

Folkman, S. F. (1997). Positive psychological states and coping with severe stress. Social Science Medicine, 45, 1207-1221.

Gerrish, N. J., Neimeyer, R. A., \& Bailey, S. (2014). Exploring maternal grief: A mixed-methods investigation of mothers' responses to the death of a child from cancer. Journal of Constructivist Psychology, 27(3), 151-173.

Gillies, J., \& Neimeyer, R. A. (2006). Loss, grief, and the search for significance: Toward a model of meaning reconstruction in bereavement. Journal of Constructivist Psychology, 19(1), 31-65.

Özafşar, M. E., Ünal, İ. H., Ünal, Y., Erul, B., ... Martı, H. (2003). Hadislerle İslam (6 Cilt). Ankara: Diyanet İşleri Başkanlığı.

Hays, J. C., \& Hendrix, C. C. (2008). The role of religion in bereavement. In M. S. Stroebe, R. O. Hansson, H. Schut, \& W. Stroebe (Eds.), Handbook of bereavement research and practice: Advances in theory and intervention (pp. 327-348). Washington, DC: American Psychological Association.

Higgins, M. P. (2002). Parental bereavement and religious factors. OMEGA-Journal of Death and Dying, 45(2), 187-207.

Holland, J. (2001). Understanding children's experiences of parental bereavement. United Kingdom: Jessica Kingsley Publishers.

Holland, J., \& Neimeyer, R. A. (2010). An examination of stage theory of grief among individuals bereaved by natural and violent causes: A meaning-oriented contribution. Omega: Journal of Death and Dying, 61(2), 103-120.

Kara, E. (2016). Yas süreci ve dini danışmanlık [The grieving process and religious counseling] [Special Issue]. Dokuz Eylül Üniversitesi İlahiyat Fakültesi Dergisi, 251-270. 
Kelly, G. A. (1955). The psychology of personal constructs. New York: Norton.

Kübler-Ross, E., \& Kessler, D. (2005). On grief and grieving. New York: Scribner.

Leahy, R.L. (2004). Bilişsel terapi ve uygulamaları (T. Özakkaş, Çev.) İstanbul: Litera Yayıncılık.

Lichtenthal, W. G., Currier, J. M., Neimeyer, R. A., \& Keesee, N. J. (2010). Sense and significance: A mixed methods examination of meaning making after the loss of one's child. Journal of Clinical Psychology, 66(7), 791-812.

Lichtenthal, W. G., \& Cruess, D. G. (2010). Effects of directed written disclosure on grief and distress symptoms among bereaved individuals. Death Studies, 34, 475-499.

Malkinson, R., \& Bar-Tur, L. (2004). Long term bereavement processes of older parents: The three phases of grief. Omega: Journal of Death and Dying, 50(2), 103-129.

Matthews, L., \& Marwit, S. (2006). Complicated grief and the trend toward cognitive behavioral therapy. Death Studies, 28, 849-863.

McIntosh, D. N., Silver, R. C., \& Wortman, C. B. (1993). Religion's role in adjustment to a negative life event: Coping with the loss of a child. Journal of Personality and Social Psychology, 65, 812-821.

Michael, S. T., Crowther, M. R., Schmid, B., \& Allen, R. S. (2003). Widowhood and spirituality: Coping responses to bereavement. Journal of Women Aging, 15, 145-165.

Miller, C., \& Loring, P. (2015). The healing power of guilt. In R. A. Neimeyer (Ed.), Techniques of grief therapy: Assessment and intervention (pp. 157-160). New York, NY: Routledge.

Murphy, S. A., Johnson, L. C., \& Lohan, J. (2003). Finding meaning in a child's violent death: A fiveyear prospective analysis of parents' personal narratives and empirical data. Death Studies, 27(5), 381-404.

Nadeau, J. W. (2001). Family construction of meaning. In R. A. Neimeyer (Ed.), Meaning reconstruction and the experience of loss (pp. 95-111). Washington, DC: American Psychological Association.

Neimeyer, R. A. (1999). Narrative strategies in grief therapy. Journal of Constructivist Psychology, $12(1), 65-85$.

Neimeyer, R. A. (2000). Searching for the meaning of meaning: Grief therapy and the process of reconstruction. Death Studies, 24(6), 541-558.

Neimeyer, R. A. (2001). The language of loss: Grief therapy as a process of meaning reconstruction. In R. A. Neimeyer (Ed.), Meaning reconstruction and the experience of loss (pp. 261-292). Washington, DC: American Psychological Association.

Neimeyer, R. A. (2004). Fostering posttraumatic growth: A narrative contribution. Psychological Inquiry, 15, 53-59.

Neimeyer, R. A. (2005). Widowhood, grief and the quest for meaning: A narrative perspective on resilience. In Carr, D., Nesse, R. M., \& Wortman, C. B. (Eds.), Late life widowhood in the United States (pp. 227-252). New York: Springer.

Neimeyer, R. A. (2006). Bereavement and the quest for meaning: Rewriting stories of loss and grief. Hellenic Journal of Psychology, 3(3), 181-188.

Neimeyer, R. A. (2011). Reconstructing meaning in bereavement: summary of a research program. Estudos de Psicologia (Campinas), 28(4), 421-426.

Pargament, K. I. (1997). The psychology of religion and coping. New York: Guilford.

Pargament, K. I., Koenig, H. G., \& Perez, L. M. (2000). The many methods of religious coping: Development and initial validation of the RCOPE. Journal of Clinical Psychology, 56, 519-543.

Pargament, K. I., \& Park, C. L. (1995). Merely a defense? The variety of religious means and ends. Journal of Social Issues, 51, 13-32. 
Park, C. L., \& Halifaxs, R. J. (2011). Religion and spirituality in adjusting to bereavement grief as burden, grief as gift. In Grief and bereavement in contemporary society (pp. 363-372). Abingdon, Oxonl: Routledge.

Parkes, C. M. (1996). Bereavement (2nd ed.). London \& New York: Routledge

Pearce, M. J., \& Smigelsky, M. A. (2015). Spiritual Journaling. In R. A. Neimeyer (Ed.), Techniques of grief therapy: Assessment and intervention (pp. 205-207). New York, NY: Routledge.

Person, E. S. (2009). On Freud's "mourning and melancholia”. London: Karnac Books.

Reilly-Smorawski, B., Armstrong, A. V., \& Catlin, E. A. (2002). Bereavement support for couples following death of a baby: Program development and 14-year exit analysis. Death Studies, 26(1), 21-37.

Rubin, S., \& Yasien-Esmael, H. (2004). Loss and bereavement among Israel's Muslims: Acceptance of God's will, grief and the relationship to the deceased. Omega: Journal of Death and Dying, 49(2), 149-162.

Savaşır, I., Boyacıoğlu, G. \& Kabakçı, E. (1996). Bilişsel davranışçı terapiler. Ankara: Türk Psikologlar Derneği Yayınları.

Smith, S. H. (2002). 'Fret no more my child... For I'm all over heaven all day": Religious beliefs in the bereavement of African American, middle-aged daughters coping with the death of an elderly mother. Death Studies, 26(4), 309-323.

Smyth, J., True, N., \& Souto, J. (2001). Effects of writing about traumatic experiences: The necessity for narrative structuring. Journal of Social and Clinical Psychology, 20(2), 161-172.

Stroebe, M., \& Schut, H. (1999). The dual process model of coping with bereavement: Rationale and description. Death Studies, 23, 197-224.

Stroebe, M., \& Schut, H. (2001). Handbook of bereavement: Consequences, coping and care. Washington, DC: American Psychologists Association.

Tedeschi, R. G., \& Calhoun, L. G. (1998). The posttraumatic growth inventory: Measuring the positive legacy of trauma. Journal of Traumatic Stress, 9, 455-471.

Tedeschi, R. G., \& Calhoun, L. G. (2004). Helping bereaved parents: A clinician's guide. New York, NY: Routledge.

Tedeschi, R. G., Tedeschi, R. G., Park, C. L., \& Calhoun, L. G. (Eds.). (1998). Posttraumatic growth: Positive changes in the aftermath of crisis. New York, NY: Routledge.

Thompson, S. C. (1985). Finding positive meaning in a stressful event and coping. Basic and Applied Social Psychology, 6, 279-295.

Uren, T. H., \& Wastell, C. A. (2002). Attachment and meaning-making in perinatal bereavement. Death Studies, 26, 279-308.

Vasegh, S. (2009). Psychiatric treatments involving religion: Psychotherapy from an Islamic perspective. In P. Huguelet \& H. G. Koening (Eds.), Religion and spirituality in psychiatry (pp. 301-316). UK: Cambridge University Press.

Walter, C. A., \& McCoyd, J. L. M. (2009). Grief and loss across the lifespan: A biopsychosocial approach. New York, NY: Springer.

Wheeler, I. (2001). Parental bereavement: The crisis of meaning. Death Studies, 25(1), 51-66.

Worden, J. W. (2009). Grief counseling and grief therapy: A handbook for mental health practitioner (4th ed.). New York: Springer.

Wortmann, J. H., \& Park, C. L. (2008). Religion and spirituality in adjustment following bereavement: An integrative review. Death Studies, 32(8), 703-736. 